\title{
Temporal Occurrence and Niche Preferences of Phytophthora spp. Causing Brown Rot of Citrus in the Central Valley of California
}

\author{
Wei Hao, Timothy D. Miles, Frank N. Martin, Gregory T. Browne, Helga Förster, and James E. Adaskaveg ${ }^{\dagger}$
}

First, fifth, and sixth authors: Department of Plant Pathology and Microbiology, University of California, Riverside 92521; second author: School of Natural Sciences, California State University, Monterey Bay, Seaside 93955; third author: Crop Improvement and Protection Research Unit, United States Department of Agriculture-Agricultural Research Service (USDA-ARS), Salinas, CA 93905; and fourth author: Crops Pathology and Genetics Research Unit, USDA-ARS, and Department of Plant Pathology, University of California, Davis 95616. Accepted for publication 18 October 2017.

\begin{abstract}
Brown rot of citrus fruit is caused by several species of Phytophthora and is currently of serious concern for the California citrus industry. Two species, Phytophthora syringae and $P$. hibernalis, are quarantine pathogens in China, a major export market for California citrus. To maintain trade and estimate the risk of exporting a quarantine pathogen, the distribution and frequency of Phytophthora spp. causing brown rot of orange in major growing areas of California was investigated. Symptomatic fruit were collected from navel (winter to late spring) and Valencia (late spring to summer) orange orchards from 2013 to 2015. Species identification of isolates was based on morphological characteristics, random amplified polymorphic DNA banding patterns, and sequencing of the internal transcribed spacer and the partial cox2/ spacer/coxl regions from axenic cultures, or directly on DNA from fruit tissue using a multiplex TaqMan quantitative polymerase chain reaction assay. In

winter samplings, the incidence of $P$. syringae based on the number of fruit with Phytophthora spp. detection ranged from 73.6 to $96.1 \%$ for the two counties surveyed. The remaining isolates were identified as $P$. citrophthora. In late spring or summer, only P. citrophthora was recovered. P. hibernalis and $P$. nicotianae were not detected in any fruit with brown rot symptoms. These results indicate that $P$. syringae is currently an important brown rot pathogen of citrus fruit in California during the cooler seasons of the year. In winter 2016 and 2017, P. syringae was recovered by pear baiting at a high incidence from leaf litter and from a small number of rhizosphere soil or root samples but not from living leaves on the tree. In contrast, P. citrophthora was rarely found in leaf litter but was commonly detected in the rhizosphere. Thus, leaf litter is a major inoculum source for $P$. syringae and this species occupies a distinct ecological niche.
\end{abstract}

Phytophthora brown rot is an important disease of citrus fruit worldwide, especially in areas and seasons with high rainfall. In California, the disease was first reported on lemon in 1907 (Smith and Ramsey 1907) and subsequently was found on all citrus species grown in the state (Feld et al. 1979). Symptoms include brown discoloration of the rind, a leathery decay texture, and typically a distinctive pungent, rancid odor. At high relative humidity, white fungal growth covers the fruit surface. Infected fruit remain firm unless there are secondary infections by other decay pathogens such as Penicillium spp. and Geotrichum citri-aurantii (Eckert and Brown 1986). Losses from brown rot can result from preharvest infections in the orchard and from postharvest fruit decay. Fruit infected in the orchard may not show any symptoms and, if infected fruit are mixed with healthy fruit during storage or shipment, brown rot may spread quickly among fruit (Erwin and Ribeiro 1996).

Worldwide, citrus brown rot is caused by several species of Phytophthora, including Phytophthora citrophthora (R. E. Sm. \& E. H. Sm.) Leonian, P. syringae (Kleb.) Kleb., P. nicotianae Breda de Haan, $P$. hibernalis Carne, P. palmivora (E. J. Butler) E. J. Butler, $P$. boehmeriae Sawada, P. cactorum (Lebert \& Cohn) J. Schröt., $P$. cinnamomi Rands, and P. citricola Sawada (Erwin and Ribeiro 1996; Graham et al. 1998). P. citrophthora, P. nicotianae, P. syringae,

†Corresponding author: J. E. Adaskaveg; E-mail: jim.adaskaveg@ucr.edu

This work was supported by a grant from the Citrus Research Board (CRB Project 5600-103) and by a grant from the Technical Assistance for Specialty Crops program, United States Department of Agriculture-Foreign Agricultural Service.

*The $\boldsymbol{e}$-Xtra logo stands for "electronic extra" and indicates that two supplementary tables are published online.

(c) 2018 The American Phytopathological Society and $P$. hibernalis have been reported from California, and the former two species are considered the main pathogens (Feld et al. 1979; Graham and Menge 2000; Klotz 1978). In contrast, in Florida, citrus brown rot is primarily caused by $P$. palmivora and $P$. nicotianae (Graham and Timmer 1995). In regions with a Mediterranean climate such as California, $P$. nicotianae is most active during the summer months, whereas $P$. citrophthora is considered most active in the remainder of the year (Dirac et al. 2003; Menge et al. 1988). $P$. syringae and $P$. hibernalis that are considered minor pathogens are adapted to lower temperatures and cause brown rot infections only during cool environmental conditions (Erwin and Ribeiro 1996). Several species, including $P$. citrophthora and $P$. nicotianae, infect not only citrus fruit but also roots and tree trunks, causing root rot and gummosis, respectively. This results in a complex disease cycle and requires an integrated management of Phytophthora diseases in citrus orchards (Graham and Menge 2000).

Brown rot is a common disease in California in the winter season, when most of the rainfall occurs. Under these conditions, zoospore inoculum is readily produced and disseminated. Still, major direct crop losses are sporadic. Indirect losses, however, have occurred in recent years to the California citrus industry because $P$. syringae and $P$. hibernalis were detected in orange (Citrus sinensis (L.) Osbeck) fruit shipments from California to China, where these species are quarantine pathogens. Export of California citrus fruit to this country, one of the major California citrus export markets with an approximate value of $\$ 140$ million (CDFA 2015), was subsequently suspended from April 2013 to August 2014. Shipment of fruit from Tulare County to China was suspended again from February to November 2015. These export restrictions resulted in extensive economic costs to growers, packinghouses, and shippers (Adaskaveg and Förster 2014). The Chinese market is open again for California growers but strict export protocols exist to manage the pathogens, including orchard sprays with copper products, pruning 
of lower branches, and orchard monitoring, as well as specific fruit harvest and handling procedures.

To estimate the risk of exporting quarantine Phytophthora spp. and maintain the California citrus export markets, the objective of this study was to identify the current causal agents of citrus brown rot in California and determine their distribution and frequency in a major production region of the state. Extensive, systematic studies on this subject have not been conducted in California in recent years; therefore, we investigated whether $P$. citrophthora and $P$. nicotianae are still the major brown rot pathogens in the state and if possibly other species are associated with the disease. We focused our collections on orange, the main concern of export restrictions, and we sampled in the growing areas of the southern Central Valley of California where most of the orange fruit are currently grown in the state. Additionally, we initiated ecological studies on survival strategies and inoculum sources of the major Phytophthora spp. causing brown rot because these have not been identified previously.

\section{MATERIALS AND METHODS}

Fruit sampling. Sweet orange fruit with brown rot symptoms were sampled in orchards in Fresno and Tulare Counties in the southern Central Valley of California in winter 2013, 2014, and 2015 (navel orange), as well as in late spring (navel and Valencia orange) and summer (Valencia orange) 2014 and 2015. Winter samplings were done from mid-January to early April and late spring or summer samplings were conducted from early May to late July. Fruit were collected from the ground or from trees. Samples were stored at $10^{\circ} \mathrm{C}$ for up to 2 days before processing. The number of orchards surveyed and samples collected every year are indicated in Table 1. From each sampled orchard, between 4 and 49 fruit were obtained.

Isolation of Phytophthora spp. from orange fruit. The symptomatic fruit were cut open using a sterilized razor blade, and five to eight clusters of juice sacs ( 8 to $64 \mathrm{~mm}^{3}$ for each cluster) from under the margin of the brown rind lesion were placed onto a modified selective Phytophthora isolation medium (Ferguson and Jeffers 1999), and a similar sample was stored at $-20^{\circ} \mathrm{C}$ for future DNA extraction. This medium (i.e., PARHFB-V8C) was prepared as follows: 1 liter of 5\% clarified V8 (V8C) agar (Ribeiro et al.
1978) was amended with $10 \mathrm{mg}$ of pimaricin (Delvocid Instant; DSM, Delft, The Netherlands), $125 \mathrm{mg}$ of ampicillin sodium salt (Sigma-Aldrich, St. Louis, MO), $10 \mathrm{mg}$ of rifampicin (SigmaAldrich), $50 \mathrm{mg}$ of hymexazol (Tachigaren 70\% WP; Gustafson, McKinney, TX), $10 \mathrm{mg}$ of fludioxonil (Scholar 50WP; Syngenta Crop Protection, Greensboro, NC), and $10 \mathrm{mg}$ of benomyl (Benlate 50DF; DuPont, Wilmington, DE). Inoculated plates were incubated at $20^{\circ} \mathrm{C}$ in the dark for up to 7 days. Colonies with hyaline, branched, coenocytic mycelium resembling those of Phytophthora spp. were subcultured (one colony per fruit), and axenic cultures were stored at $20^{\circ} \mathrm{C}$ in the dark for further identification. Isolation of Phytophthora spp. was done for all fruit samples from the 2013 and 2014 surveys, and species identification was based on cultural characteristics, sequence analyses, and random amplified polymorphic DNA (RAPD) fragment patterns (see below). Following the development of the multiplex TaqMan quantitative polymerase chain reaction (qPCR) assay that is described below, species identification in 2015 was done directly from samples of infected plant tissues.

Grouping of Phytophthora isolates by cultural characteristics. Cultural characteristics used included the presence or absence of reproductive and survival structures (e.g., sporangia, oospores, and chlamydospores) after 4 to 6 weeks of growth on PARHFB-V8C medium. Isolates in each group were further evaluated for their mycelial growth pattern (e.g., petaloid/stellate or cottony). Isolates with a petaloid/stellate mycelial growth pattern were subgrouped based on the distance (i.e., $<10 \mathrm{~mm}$ or $>10 \mathrm{~mm}$ ) from the center of the plate to the tip of the longest mycelial lobe.

DNA extraction from fungal mycelium and orange fruit tissue. Approximately $60 \%$ of isolates from each morphological group and subgroup (in total, 122 and 243 isolates obtained in winter 2013 and 2014, respectively, and 43 isolates obtained in late spring and summer 2014) were randomly selected and used for DNA extraction. Isolates were grown in 10\% V8C broth (Ribeiro et al. 1978) at $20^{\circ} \mathrm{C}$ in the dark for 5 to 7 days. Mycelia were collected and rinsed with sterile distilled water, and DNA was extracted using a phenol-chloroform method (Judelson 1996). DNA extracts were stored at $-20^{\circ} \mathrm{C}$.

A modified protocol of the FastDNA SPIN Kit (MP Biomedicals, LLC, Solon, $\mathrm{OH}$ ) was used to extract DNA from fruit tissue. Tissue that was obtained as described above was homogenized in $400 \mu \mathrm{l}$ of

TABLE 1. Survey of orange orchards in Fresno and Tulare Counties in 2013, 2014, and 2015 for the presence of fruit brown rot and Phytophthora spp. identified ${ }^{\mathrm{a}}$

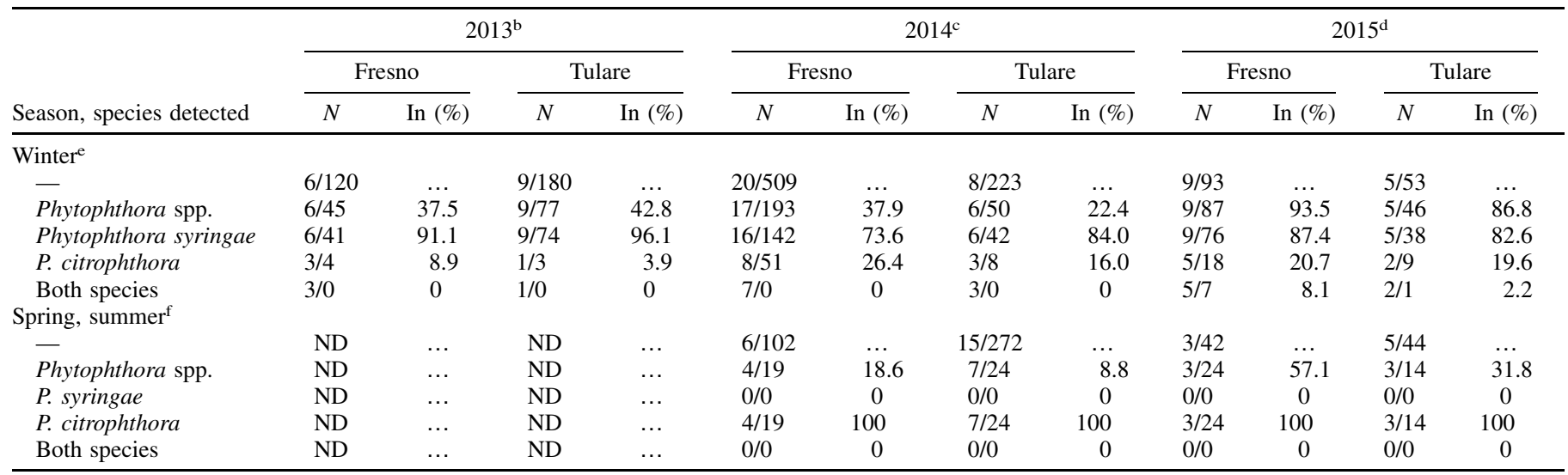

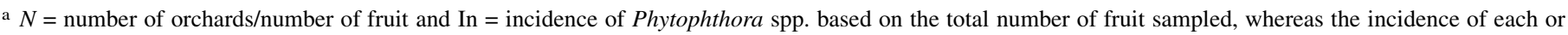
both species is based on the total number of Phytophthora isolates detected. ND = not done.

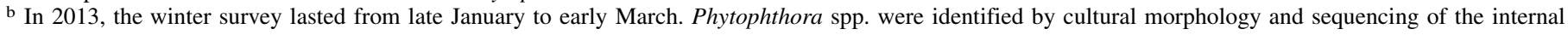
transcribed spacer and cytochrome oxidase subunit regions.

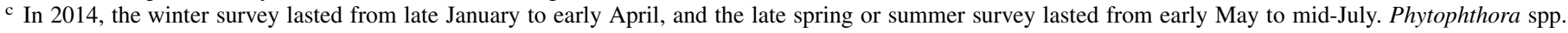
were identified after isolation by random amplified polymorphic DNA analysis.

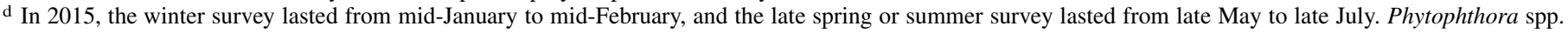
were identified directly in orange tissue by TaqMan quantitative polymerase chain reaction assays.

e In the winter surveys, all samples were navel orange.

f In late spring and summer surveys, all samples in 2014 were Valencia orange. In 2015, navel orange fruit were sampled in two orchards. 
$10 \mathrm{mM}$ Tris- $\mathrm{HCl}(\mathrm{pH} 8.0)$ and $100 \mu \mathrm{l}$ of $7.5 \mathrm{M}$ ammonium acetate with the aid of a stainless-steel grinding ball (Steelball Lysing Matrix Bulk; MP Biomedicals, LLC) using the FastPrep-24 Instrument (MP Biomedicals, LLC) at $6.0 \mathrm{~m} / \mathrm{s}$ twice for $45 \mathrm{~s}$. After centrifugation at $16,000 \times g$ for $10 \mathrm{~min}, 50 \mu \mathrm{l}$ of binding matrix and $400 \mu \mathrm{l}$ of Salton Wash 1 were added to the supernatant. The tube was inverted 10 times and incubated for $10 \mathrm{~min}$ at $25^{\circ} \mathrm{C}$. After centrifugation for $1 \mathrm{~min}$ at $16,000 \times \mathrm{g}$, the pellet was washed with $200 \mu \mathrm{l}$ of Salton Wash number 1 and then with $600 \mu$ of SEWS-M wash solution of the FastDNASPIN Kit. The pellet was collected and air dried, and the DNA was resuspended by incubation in $50 \mu \mathrm{l}$ of sterile ultrapure water at $55^{\circ} \mathrm{C}$ for $10 \mathrm{~min}$.

Identification of Phytophthora spp. by sequencing of the ribosomal DNA internal transcribed spacer region and of the partial cytochrome oxidase subunit $2 /$ spacer/cytochrome oxidase subunit 1 region. Sequence analyses were performed for six representative isolates of Phytophthora obtained in winter 2013 and for 35 and 13 isolates obtained in winter and late spring or summer 2014, respectively. Universal primers internal transcribed spacer (ITS)6 and ITS4 (Table 2) (Cooke and Duncan 1997; Cooke et al. 2000; White et al. 1990) were used for the ITS region, and primers FM35 and FMPhy-10b (Table 2) (Martin 2000; Martin et al. 2004) were used for the cytochrome oxidase subunit (cox)2/ spacer/coxl region. Each $25-\mu 1$ reaction contained $1 \mu \mathrm{l}$ of DNA extract (10 to $20 \mathrm{ng}$ DNA), $2.5 \mu \mathrm{l}$ of $10 \times$ PCR buffer containing $150 \mu \mathrm{M} \mathrm{MgCl}_{2}$ (Apex; Genesee Scientific, San Diego, CA), $200 \mu \mathrm{M}$ dNTP, $2.5 \mu \mathrm{g}$ of bovine serum albumin (BSA), $0.4 \mu \mathrm{M}$ each primer, and $1.25 \mathrm{U}$ of Taq DNA polymerase (Apex; Genesee Scientific). PCR was performed using a Programmed Thermal Controller (PTC-100; MJ Research, Inc., Watertown, MA) with conditions as follows: initial denaturation at $95^{\circ} \mathrm{C}$ for $2 \mathrm{~min} ; 35$ cycles of denaturation at $95^{\circ} \mathrm{C}$ for $30 \mathrm{~s}$, annealing at $55^{\circ} \mathrm{C}$ for ITS primers or $58^{\circ} \mathrm{C}$ for cox primers for $30 \mathrm{~s}$, and extension at $72^{\circ} \mathrm{C}$ for $30 \mathrm{~s}$; and a final extension at $72^{\circ} \mathrm{C}$ for $2 \mathrm{~min}$. Successful amplification was confirmed by agarose (GenePure LE Agarose; ISC BioExpress, Kaysville, UT) gel electrophoresis of an amplification aliquot in $0.5 \times$ Tris-borate-EDTA buffer and staining with ethidium bromide.

PCR products were treated with ExoSap-IT (USB, Affymetrix, Inc., Cleveland, $\mathrm{OH}$ ) according to the manufacturer's instructions to remove excess primers and nucleotides. Sequencing was done in both directions with the same primers as for amplification of the ITS region. Primers FM79 and FM80 (Table 2) (Martin and Tooley 2003) were used to sequence $123 \mathrm{bp}$ of the $3^{\prime}$ end of the cox 2 gene, the spacer region, and $65 \mathrm{bp}$ of the $5^{\prime}$ end of the coxl gene in a standard Sanger dideoxy sequencing reaction using a 3730 XL DNA analyzer (ABI; Institute for Integrative Genome Biology, University of California, Riverside). Sequences were subjected to a BLAST search (https://blast.ncbi.nlm.nih.gov/Blast.cgi) to determine the highest maximum identities to sequences in GenBank.

Identification of Phytophthora spp. by RAPD fragment patterns. DNA from 136 isolates obtained in winter 2014 and 25 isolates from late spring or summer 2014, including all those that were used for ITS and cox $2 /$ spacer/coxl region sequence analyses, as well as from reference isolates of $P$. syringae (4865 and 4870), P. citrophthora (4866 and 4867), P. nicotianae (2348 and 2390), and $P$. hibernalis (1369 and 1370), was amplified using random primers OPI-17, OPS-12, and OPY-07 (Table 2) (Operon Technologies, Inc., Alameda, CA). For each reaction, template DNA at 10 to $20 \mathrm{ng} / \mu \mathrm{l}$ was used. PCR were performed using a CFX96 C1000 Thermal Cycler (Bio-Rad Laboratories, Inc., Hercules, CA) with the following conditions: initial denaturation at $94^{\circ} \mathrm{C}$ for $30 \mathrm{~s} ; 35$

TABLE 2. Amplification, random amplified polymorphic DNA (RAPD), and sequencing primers, as well as Phytophthora genus-specific, Phytophthora spp.specific, and plant TaqMan quantitative polymerase chain reaction (qPCR) probes used in this study

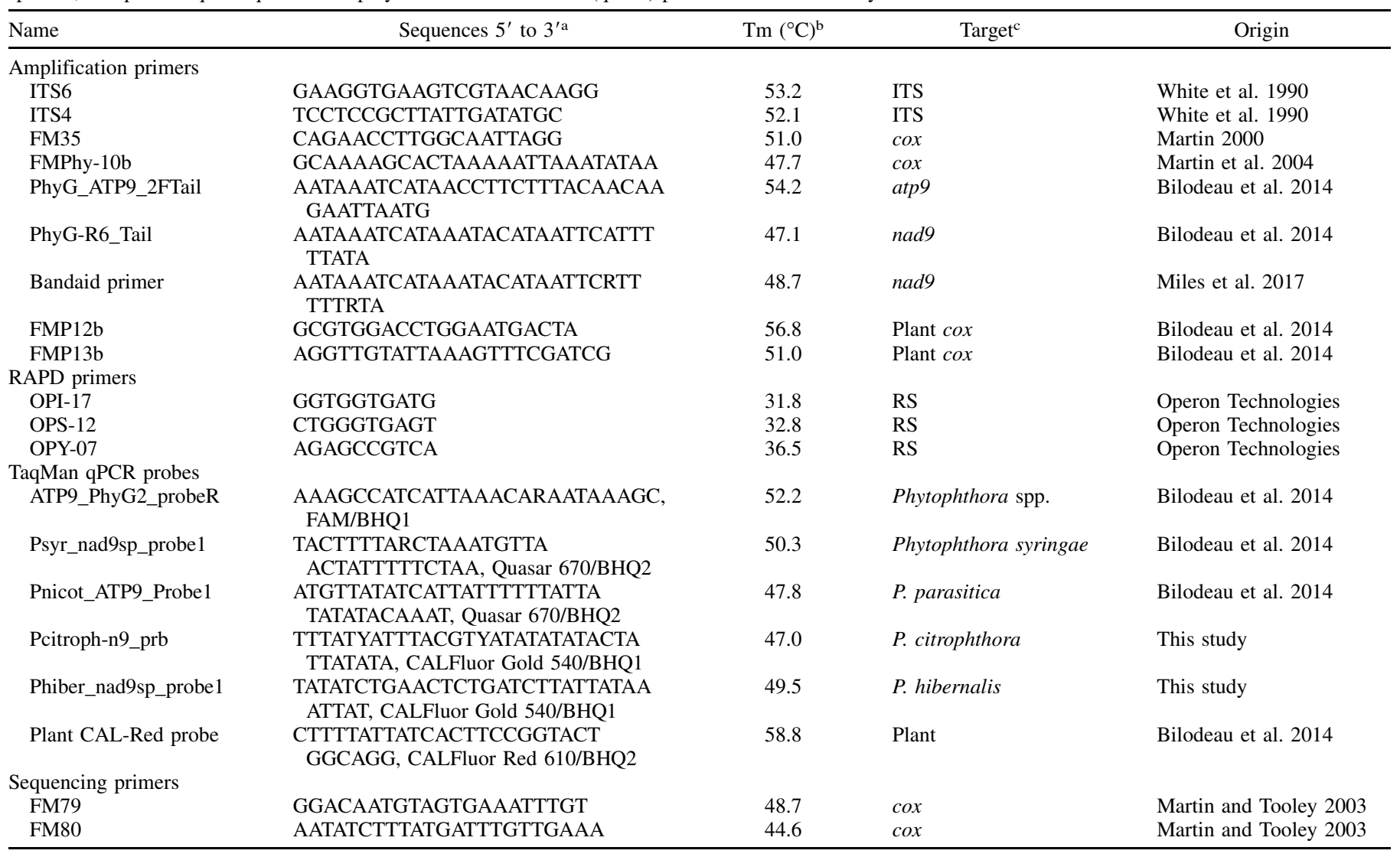

a Fluorophores and quenchers are denoted after the sequences for TaqMan qPCR probes.

b Calculated primer or probe melting temperature was calculated using the OligoAnalyzer 3.1 (Integrated DNA Technologies, Coralville, IA).

${ }^{c}$ ITS = internal transcribed spacer, $\operatorname{cox}=$ cytochrome oxidase subunit, and RS = random sequence. 
cycles of: denaturation at $94^{\circ} \mathrm{C}$ for $1 \mathrm{~min}$, annealing at $35^{\circ} \mathrm{C}$ for $1 \mathrm{~min}$, and extension at $72^{\circ} \mathrm{C}$ for $2 \mathrm{~min}$; and a final extension at $72^{\circ} \mathrm{C}$ for $7 \mathrm{~min}$. Reaction mixtures were prepared as described above, except that no BSA was added and only a single primer was used. Amplification products were visualized as described above. Banding patterns of unknown isolates were compared with those of reference isolates.

Identification of Phytophthora spp. in orange fruit using a multiplex TaqMan qPCR assay. Phytophthora genus PhyG_ATP9_2FTail, PhyG-R6_Tail, and bandaid primers (Table 2) were designed from conserved regions of the atp9 and nad 9 mitochondrial genes, and the genus probe ATP9_PhyG2_probeR was based on a conserved portion of the atp 9 gene (Bilodeau et al. 2014; Miles et al. 2017). The P. syringae-specific probe Psyr_nad9sp_probe1 and the $P$. nicotianae-specific probe Pnicot_ ATP9_Probe1 were designed from intergenic spacer sequences of the atp9-nad9 locus (Bilodeau et al. 2014). Species-specific probes for P. citrophthora (Pcitroph-n9_prb) and P. hibernalis (Phiber_ nad9sp_probe1) were newly designed from intergenic spacer sequences of the atp9-nad 9 locus and were validated in this study. Sequences of TaqMan qPCR primers and probes used are listed in Table 2. The specificity of these two latter probes was tested against 117 Phytophthora taxa (131 isolates), 2 Pythium spp. (2 isolates), and 1 Phytopythium sp. (2 isolates) (Jung and Burgess 2009; Martin et al. 2014). These isolates were from the World Phytophthora Genetic Resource Collection at the University of California, Riverside, and are listed in Supplementary Table S1. The amplification efficiency and sensitivity of the probes were evaluated using standard curves based on serial dilutions of DNA from $P$. citrophthora isolate 4866 (87 $\mathrm{ng}$ to $0.5 \mathrm{pg}$ per reaction) or P. hibernalis isolate 1369 (269 $\mathrm{ng}$ to 0.5 pg per reaction). DNA was quantified using a NanoDrop 1000 spectrophotometer (Thermo Fisher Scientific Inc., Wilmington, DE). Plant primers FMPl2b and FMPl3b, as well as plant probe Plant CALRed, were also included in each reaction as an internal control (Table 2) (Bilodeau et al. 2014). Each 25- $\mu$ l multiplex reaction included $1 \mu \mathrm{l}$ of 10 to $20 \mathrm{ng}$ of DNA, $10 \mu \mathrm{l}$ of RealMasterMix Probe (5 PRIME GmbH, Germany), Phytophthora genus primers $(0.5 \mu \mathrm{M}$ each) and probe $(0.05 \mu \mathrm{M})$, two Phytophthora spp.-specific probes $(0.05 \mu \mathrm{M}$ each), plant primers $(0.0125 \mu \mathrm{M}$ each $)$ and probe $(0.01 \mu \mathrm{M})$, bandaid primer $(0.004 \mu \mathrm{M})$, and $6 \mathrm{mM} \mathrm{MgCl}_{2}$ (Supplementary Table S2). Reactions were amplified as described by Bilodeau et al. (2014) using a CFX96 $\mathrm{C} 1000$ Thermal Cycler at the following conditions: $95^{\circ} \mathrm{C}$ for $2 \mathrm{~min}$ followed by 50 cycles of denaturation at $95^{\circ} \mathrm{C}$ for $15 \mathrm{~s}$ and annealing or extension at $57^{\circ} \mathrm{C}$ for $1.5 \mathrm{~min}$. Either $P$. syringae- and $P$. citrophthoraspecific probes or $P$. nicotianae- and $P$. hibernalis-specific probes were paired in a multiplex qPCR.

To determine the consistency of Phytophthora sp. detection using fungal isolation or TaqMan qPCR, 56 samples obtained from different orchards in 2014 were used, including 31 samples from which $P$. syringae was isolated and 25 samples from which P. citrophthora was isolated. Additionally, 51 samples from the 28 orchards surveyed in winter 2014 where no Phytophthora sp. was isolated were also evaluated by TaqMan qPCR. Subsequently, this assay was used for all samples collected in winter and late spring or summer 2015.

Detection of Phytophthora spp. in orchard environmental samples. In winter 2016 and 2017, leaf litter on the ground, living leaves on the tree, rhizosphere soil with roots, as well as fruit with brown rot were sampled from four and six orange orchards located in Fresno and Tulare Counties, respectively. In our 2013 to 2015 surveys, these orchards had high incidences of $P$. syringae. In each orchard and for each sampling, three or four replicates were collected for each type of sample. Each fruit sample consisted of up to 15 fruit with brown rot symptoms, whereas leaf litter and living leaf sample replicates each consisted of 10 to 20 leaves. Rhizosphere samples (approximately 80 to $100 \mathrm{~g}$ of a composite of soil with root fragments from four locations around each tree) were obtained from a depth of 10 to $15 \mathrm{~cm}$ at the dripline of each tree.
Several approaches were used for detection of brown rot pathogens in the samples. The presence of Phytophthora spp. in fruit was determined directly by TaqMan qPCR, as described above. Detection of brown rot pathogens in leaf litter, living leaves, and rhizosphere samples was accomplished by pear baiting; each sample type was immersed in 400 to $500 \mathrm{ml}$ of deionized water in 1-liter plastic bags, and one mature D'Anjou pear was placed into each bag. The bags were incubated at $12^{\circ} \mathrm{C}$ for up to 4 weeks. Internal tissue from the margin of brown decay lesions on pear fruit was plated onto PARHFB-V8C medium, plates were incubated at $20^{\circ} \mathrm{C}$, and Phytophthora isolates were identified by TaqMan qPCR, as described above.

\section{RESULTS}

Grouping of Phytophthora isolates from orange fruit with brown rot symptoms by cultural characteristics. Chlamydospores were not observed on PARHFB-V8C medium in any of the cultures of Phytophthora obtained in 2013 and 2014 but some of the isolates produced oospores. All isolates from 2013 and 2014 were placed into two groups based on oospore presence (i.e., group I = oospores present and group II = oospores absent). Group I isolates all had a petaloid to stellate mycelial growth pattern. Based on the distinctness of the pattern and the distance from the center of the plate to the tip of the longest mycelial lobe, group I isolates were further divided into three subgroups. Subgroups Ia, Ib, and Ic had a slightly petaloid pattern and a lobe distance of $<10 \mathrm{~mm}$, a less-defined petaloid pattern with a lobe distance of $>10 \mathrm{~mm}$, and a distinct petaloid pattern with a lobe distance of $>10 \mathrm{~mm}$, respectively. All isolates in group II shared a very similar, more uniform mycelial growth pattern. Variously shaped (e.g., ovoid, ellipsoid, and obturbinate) sporangia were observed in some isolates of group II. Mycelial growth rates of representative isolates in group I were lower (2.8 to $3.6 \mathrm{~mm} /$ day) than those of isolates in group II (4.3 to $5 \mathrm{~mm} /$ day) at $20^{\circ} \mathrm{C}$ on PARHFB-V8C medium. Mycelial growth patterns of representative isolates of groups and subgroups are shown in Figure 1. Morphological groups I and II were both present among isolates obtained in winter 2013 and 2014, whereas only morphological group II was observed among isolates obtained in late spring and summer 2014.

Identification of Phytophthora spp. by sequencing of the ribosomal DNA ITS and cox $2 /$ spacer/cox 1 regions. ITS sequences obtained were 862 to $941 \mathrm{bp}$ and $\operatorname{cox} 2 /$ spacer/cox 1 sequences were 390 to 416 bp in length. BLAST searches indicated that sequences of three representative isolates of the three subgroups of morphological group I were all identical to reference sequences of $P$. syringae, whereas three sequences of group II isolates were identical to those of $P$. citrophthora. Furthermore, sequences for 48 additional isolates (24 each of $P$. syringae and $P$. citrophthora) that were identified by RAPD analysis as described below matched those of the respective species and all sequences were identical within a species. Representative sequences were deposited in GenBank (ITS sequence accession numbers KY608276 and KY608279 for P. syringae isolates 4865 and 4870, respectively, and KY608277, KY608278, KY608280, and KY608281 for P. citrophthora isolates 4866, 4867, 4872, and 4873, respectively; cox2/spacer/cox1 sequence accession numbers KY608282 and KY608285 for P. syringae isolates 4865 and 4870, respectively, and KY608283, KY608284, KY608286, and KY608287 for P. citrophthora isolates 4866, 4867, 4872, and 4873, respectively).

Identification of Phytophthora spp. by RAPD fragment patterns. Using three random primers, distinct banding patterns were observed for reference isolates of $P$. syringae, $P$. citrophthora, $P$. nicotianae, and $P$. hibernalis (Fig. 2). The two isolates of $P$. syringae showed identical patterns in amplifications with primers Y-07 and S-12 whereas, with primer I-17, minor differences were observed. The two isolates of $P$. citrophthora had different patterns with each of the three primers but the majority of bands were shared. 
Banding patterns using the three primers were distinct for $P$. nicotianae and $P$. hibernalis, and they were identical for the two isolates of each species evaluated.

RAPD banding patterns of representative isolates of morphological group I obtained in 2014 were identical to those of the reference isolates of $P$. syringae; 167 isolates evaluated matched reference isolate 4870 and 17 matched isolate 4865 . Isolates of morphological group II all produced banding patterns identical to the two reference isolates of $P$. citrophthora; 100 of the 102 isolates evaluated

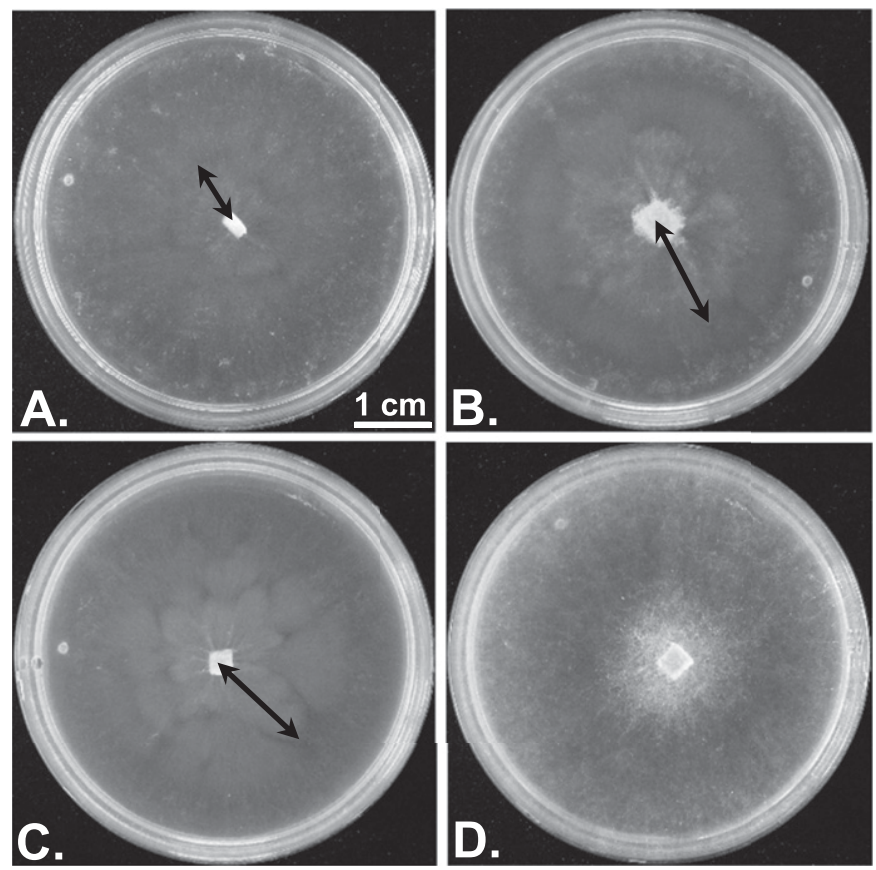

Fig. 1. Cultural characteristics of Phytophthora spp. isolates from orange fruit with brown rot symptoms based on the presence or absence of oospores and colony morphology. A, Group Ia: oospores present, colony with a slightly petaloid pattern/distance from the center of the plate to the tip of the longest lobe (arrow) $<10 \mathrm{~mm} ; \mathbf{B}$, group Ib: oospores present, colony with a less defined petaloid pattern and with lobe distance (arrow) $>10 \mathrm{~mm}$; C, group Ic: Oospores present, colony with a distinct petaloid pattern and with lobe distance (arrow) $>10 \mathrm{~mm}$; and $\mathbf{D}$, group II: oospores absent, nonpetaloid growth pattern. Cultures are 4 to 6 weeks old and are growing on PARHFB-V8C medium. Groups Ia, Ib, and Ic were ultimately identified as Phytophthora syringae, whereas group II was identified as $P$. citrophthora. matched reference isolate 4867, while two were identical to isolate 4866. Additionally, RAPD banding patterns for the 48 isolates from winter and late spring or summer 2014 that were used for ITS and cox $2 /$ spacer/coxl region sequence analyses also identified the same 24 isolates as $P$. syringae and the same 24 isolates as P. citrophthora.

Identification of Phytophthora spp. in fruit tissue using a multiplex TaqMan qPCR assay. The TaqMan qPCR probes that were newly designed for $P$. citrophthora and $P$. hibernalis and validated by testing against 117 species of Phytophthora, 2 of Pythium, and 1 of Phytopythium were found to be highly specific for the respective species (data not presented). Standard curves of the two probes (Fig. 3) demonstrated a linear relationship between cycle threshold $\left(\mathrm{C}_{\mathrm{t}}\right)$ values and amount of DNA used per reaction with $R^{2}$ values of 0.999 . Amplification efficiencies calculated as $\left[10^{(-1 / \text { slope })}-1\right] \times 100$ were $106 \%$ for the $P$. citrophthora-specific probe and $104 \%$ for the $P$. hibernalis-specific probe.

There was a high level of agreement in species assignment based on identification of Phytophthora isolates by RAPD banding patterns and direct detection in fruit tissue by TaqMan qPCR for 56 samples evaluated. Among 31 samples that yielded $P$. syringae isolations, $P$. syringae was detected by TaqMan qPCR in all samples, and both $P$. syringae and $P$. citrophthora were detected in one sample. $\mathrm{C}_{\mathrm{t}}$ values of the Phytophthora genus and P. syringae-specific probes ranged from 16.6 to 25.4 and 18.7 to 27.7, respectively. Similarly, among 25 samples from which $P$. citrophthora was isolated, $P$. citrophthora was detected by TaqMan qPCR in all samples and both species were detected in two samples. $\mathrm{C}_{\mathrm{t}}$ values of the Phytophthora genus and the $P$. citrophthora-specific probes ranged from 15.5 to 24.0 and 17.7 to 26.0 , respectively. $C_{t}$ values for the plant probe that was used as an internal control ranged from 15.7 to 22.2 .

Among 51 orange samples where isolations were not successful, Phytophthora spp. were detected by TaqMan qPCR in 17 samples using the Phytophthora genus probe $\left(\mathrm{C}_{\mathrm{t}}\right.$ values 19.1 to 26.7). $P$. syringae was detected in 16 of the samples $\left(\mathrm{C}_{\mathrm{t}}\right.$ values 21.3 to 28.7$)$ and $P$. citrophthora was detected in one sample $\left(\mathrm{C}_{\mathrm{t}}\right.$ value 24.2$)$ using the respective probes. The plant probe was positive in all 51 samples $\left(C_{t}\right.$ values 18.1 to 25.2$)$, indicating that the extracted DNA was amplifiable.

Seasonal frequency and distribution of Phytophthora spp. causing brown rot of orange fruit. In total, 1,638 orange fruit with symptoms resembling brown rot were collected from 52 orchards in two of the main citrus-growing counties of California between winter 2013 and summer 2015. Each year, the majority was collected during the winter. Phytophthora brown rot was positively
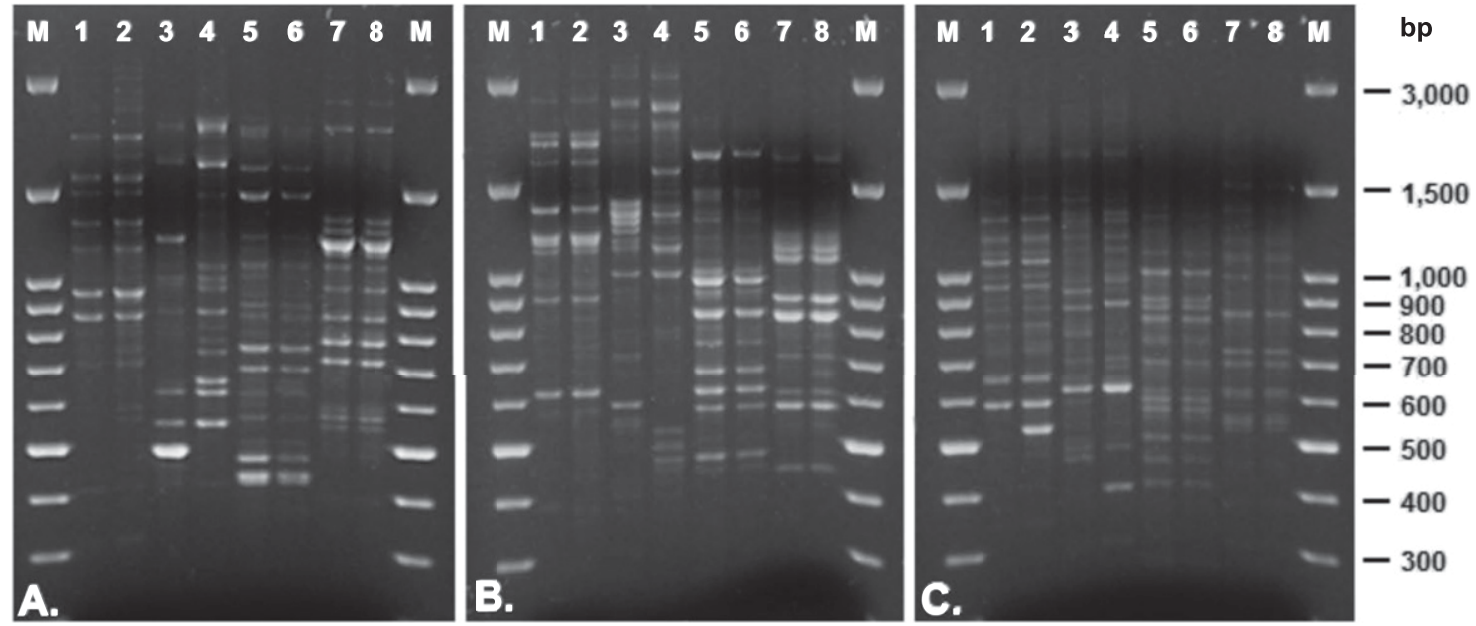

Fig. 2. Agarose gel banding patterns of random amplified polymorphic DNA polymerase chain reaction products of Phytophthora spp. amplified with primers A, OPY-07; B, OPS-12; or C, OPI-17. Lanes 1 and 2: Phytophthora syringae isolates 4865 and 4870, lanes 3 and 4: P. citrophthora isolates 4866 and 4867 , lanes 5 and 6: P. nicotianae isolates 2348 and 2390, lanes 7 and 8: P. hibernalis isolates 1369 and 1370, and lane M: 100-bp ladder. 
identified in the majority of orchards surveyed, with the highest incidence of detection in the 2015 winter season, when TaqMan qPCR was used for direct detection in fruit tissue (Table 1).

In the three winter surveys in both counties, brown rot of orange was determined to be caused primarily by $P$. syringae (Table 1 ). The incidence of $P$. syringae among isolates ranged between $73.6 \%$ (Fresno County 2014) and 96.1\% (Tulare County 2013). The remaining isolates were identified as $P$. citrophthora. The latter species was the sole pathogen associated with brown rot in only one orchard (Fresno County, winter 2014; eight isolates obtained in total); in other orchards, either $P$. syringae only or both pathogens were present. In contrast, in late spring or summer samplings, only P. citrophthora was detected in diseased fruit (Table 1). P. nicotianae and $P$. hibernalis were not detected in any of the samples.

Detection of Phytophthora spp. in leaf litter, living leaves, and rhizosphere samples. Green pear fruit used as baits successfully detected Phytophthora spp. in orchard samples. Up to 20 firm, brown lesions developed on the skin of each fruit starting at the water line and were determined to be caused by Phytophthora spp. Except for one leaf litter sample, P. citrophthora was recovered from the rhizosphere soil and root samples in all 10 orchard locations, even when only $P$. syringae was detected in orange fruit with brown rot (Fig. 4). In contrast, $P$. syringae was found to be present in leaf litter in nine locations, and at low incidence in the rhizosphere of four locations. No Phytophthora sp. was recovered from any living leaf sample.

\section{DISCUSSION}

Extensive samplings of orange fruit with brown rot symptoms between winter 2013 and summer 2015 in two of the main counties in the southern Central Valley of California where the crop is grown demonstrated the widespread occurrence of $P$. syringae. The species accounted for between 73.6 and $96.1 \%$ of the Phytophthora-positive detection in the winter months, and the remaining isolates were identified as $P$. citrophthora. In limited samplings, $P$. syringae was also found to cause brown rot of citrus fruit in Riverside and Solano Counties (data not presented) that are over $300 \mathrm{~km}$ to the south or north, respectively, from the sampled Fresno and Tulare Counties. $P$. syringae was not detected in late spring or summer samplings. The seasonal presence of this species is consistent with its lower temperature optimum for growth (i.e., 15 to $20^{\circ} \mathrm{C}$ ) (Erwin and Ribeiro 1996) and with its previously described occurrence during the cooler times of the year (Eckert and Eaks 1989).

The main species of Phytophthora that were previously associated with citrus brown rot in California are P. citrophthora and P. nicotianae (Feld et al. 1979; Klotz 1978), whereas P. syringae and $P$. hibernalis were considered pathogens of limited distribution (Graham and Menge 2000). We identified P. citrophthora as the only species causing brown rot in late spring or summer, and $P$. nicotianae and $P$. hibernalis were not detected in any of our samplings. Isolation plates were incubated at $20^{\circ} \mathrm{C}$ that would have supported growth of all four species. In addition, the latter two species were also not detected using molecular assays. Therefore, P. nicotianae and P. hibernalis are currently brown rot pathogens of minor importance in California, whereas $P$. syringae has become a major pathogen. Still, P. nicotianae, together with $P$. citrophthora, is commonly causing Phytophthora root rot of citrus in California (Hao et al. 2016).

Morphological characteristics, DNA sequencing, and RAPD banding patterns of Phytophthora isolations were used for species identification in the first 2 years before the TaqMan qPCR assay was developed. Identification by RAPD banding patterns and sequence analyses correlated well, and the RAPD assay proved to be an accurate and rapid method for species assignment of Phytophthora isolations. Phytophthora spp., however, are known to be difficult to isolate from plant tissues that are necrotic or are colonized by secondary organisms (Erwin and Ribeiro 1996). Therefore, our isolation recovery of the brown rot pathogens was likely less efficient for pathogen detection than using molecular methods. Direct identification in diseased fruit tissue using TaqMan qPCR assays with species-specific probes (some of them newly developed) proved to be a much more rapid method. There was a high correlation in species identification for 56 orange samples collected in 2014 among the methods used. TaqMan qPCR also was more sensitive in detecting Phytophthora spp. Thus, among 51 samples from winter 2014 where isolations were not successful, Phytophthora spp. were detected in 17 samples. Detection limits for Phytophthora spp. were determined to be $500 \mathrm{fg}$ of pathogen DNA per reaction. However, Bilodeau et al. (2014) and Miles et al. (2017), working with other Phytophthora spp. and probes, could still detect $100 \mathrm{fg}$ of pathogen DNA in a qPCR. Multiplexing allowed detection of Phytophthora at the genus level and of two species in a single reaction, and primers and probe for plant DNA served as an internal control for amplification quality. An additional advantage of this assay is that the Phytophthora genus-specific amplicon can be sequenced for species identification in the event that there is no detection using selected species-specific TaqMan probes (Bilodeau et al. 2014; Miles et al. 2017).

Phytophthora spp. were detected at a much higher incidence in brown-rot-affected fruit samples in the 2015 winter season than in the other collecting periods. This can be attributed to the use of the highly sensitive TaqMan qPCR method for these samples. However,
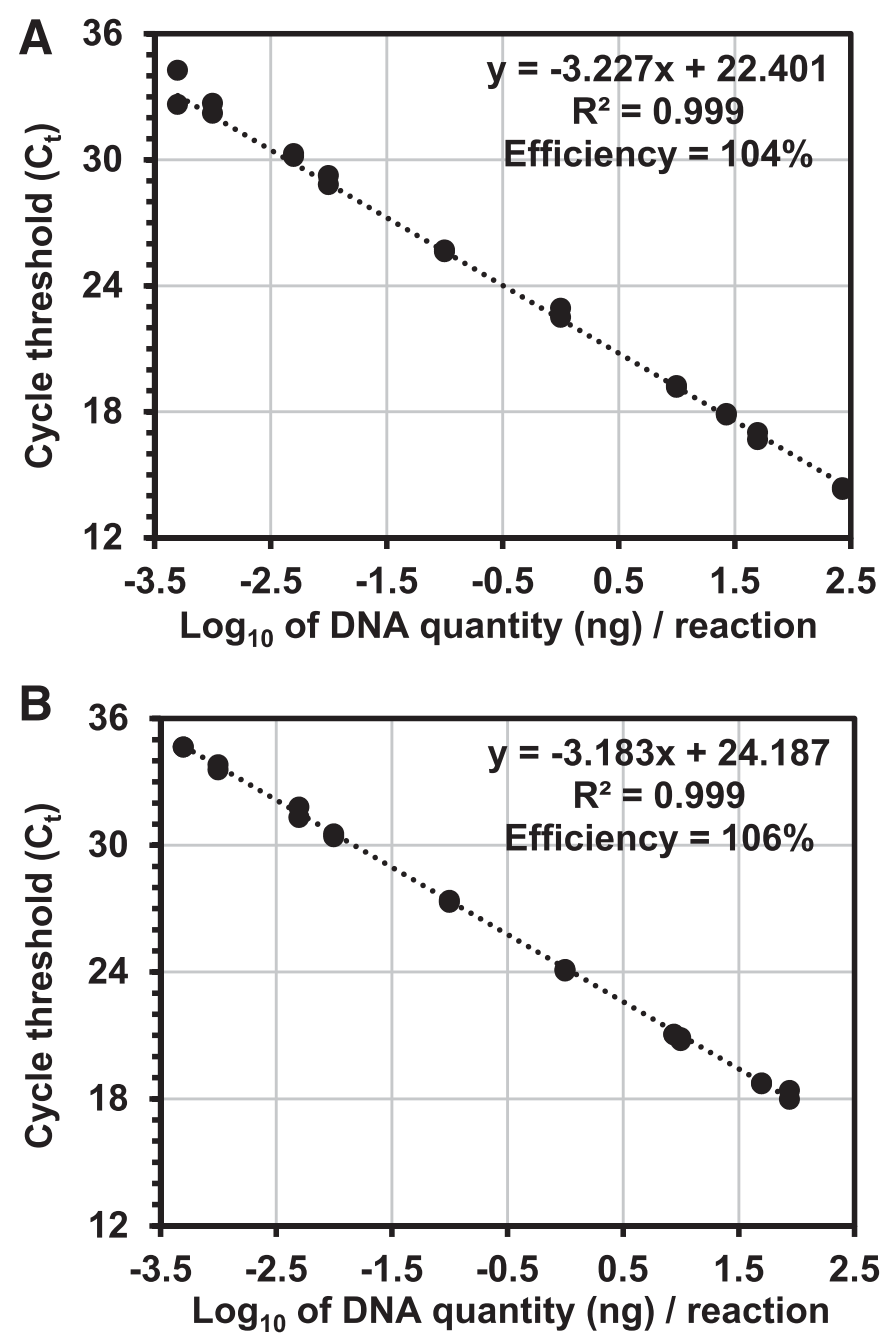

Fig. 3. Standard curves of TaqMan quantitative polymerase chain reaction using the A, Phytophthora citrophthora-specific probe (Pcitroph_n9_prb) and B, $P$. hibernalis-specific probe (phiber_nad9sp-probe1), both based on the intergenic spacer region of mitochondrial atp 9 and nad 9 genes. Duplicate dilutions of mycelial DNA from $87 \mathrm{ng}$ to $0.5 \mathrm{pg}$ per reaction for P. citrophthora (isolate 4866) and from $269 \mathrm{ng}$ to $0.5 \mathrm{pg}$ per reaction for $P$. hibernalis (isolate 1369) were used. Regression equation, correlation coefficients, and reaction efficiency are indicated. 


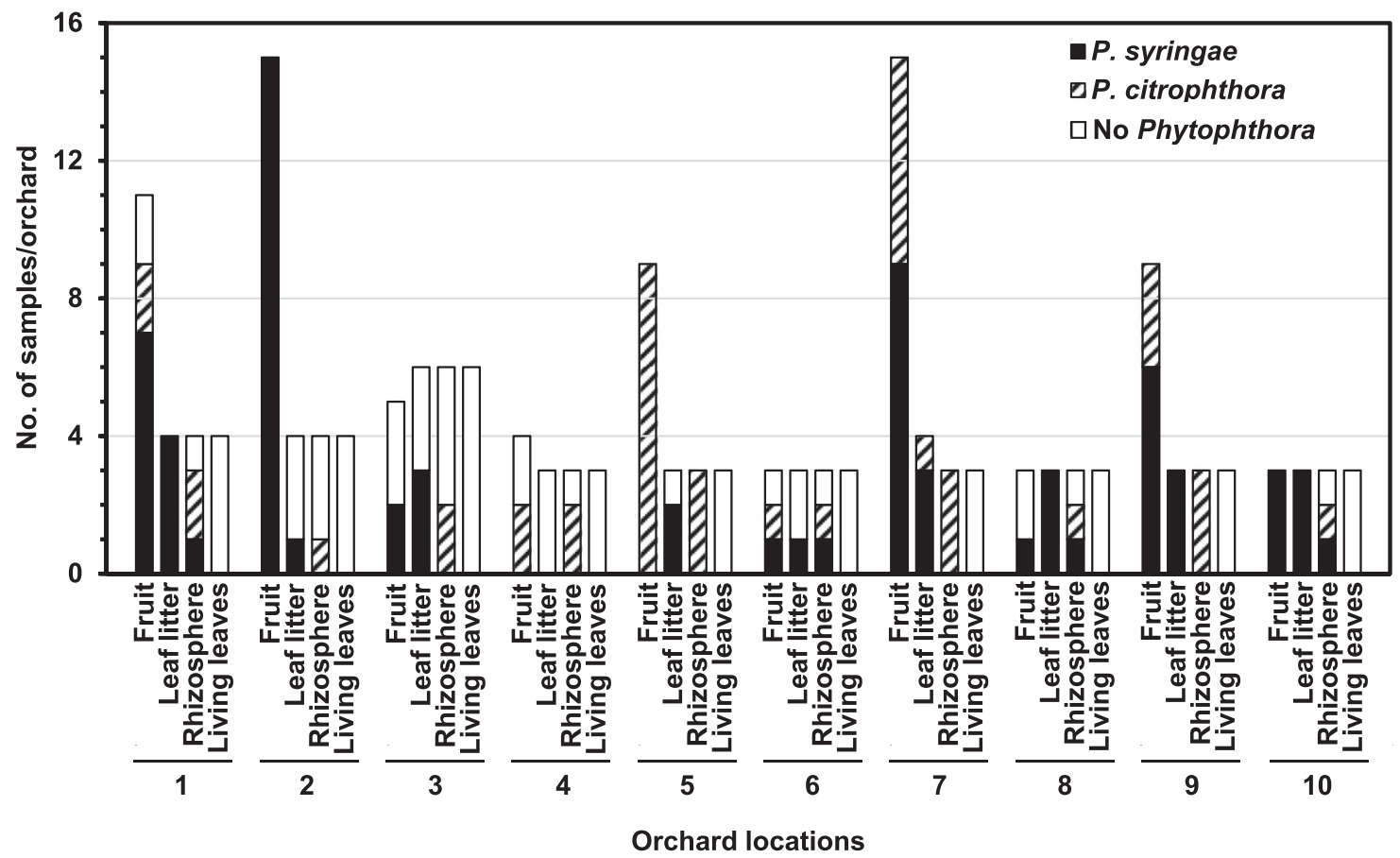

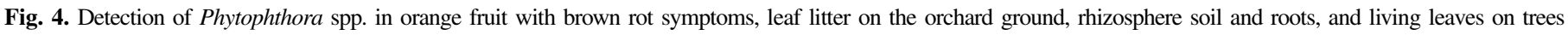

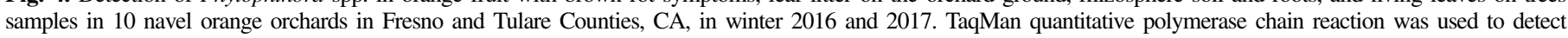

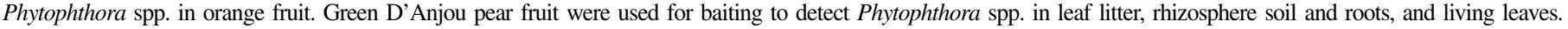

detection in late spring or summer 2015 samples, where TaqMan qPCR was also used, was relatively low, although still higher than in late spring or summer of the previous year. Samples were collected in the field based on visual symptoms of brown rot. The disease is more difficult to identify during dry conditions in the warmer seasons when fruit become desiccated, the typical odor is less prevalent, and fruit with Phytophthora brown rot are not as easily differentiated from fruit that are browndiscolored due to other reasons (e.g., sunburn, fruit senescence, or other decays). Therefore, some of the orange fruit samples evaluated may have been misidentified as having brown rot during collecting.

Another important finding of our study is the detection of $P$. syringae in leaf litter in orange orchards in the winter season. P. nicotianae and $P$. citrophthora are known citrus root pathogens, and also can be readily recovered in soil plating (Erwin and Ribeiro 1996; Hao et al. 2016). $P$. syringae, however, has never been isolated from citrus roots (Hao et al. 2016), and the low recovery of $P$. syringae from rhizosphere samples may be due to contamination from leaf litter above the collected rhizosphere samples.

Ideally, all symptomatic orange should be collected directly from the tree in fruit brown rot surveys and not from the orchard floor, as was done for some of our samples. This, however, is often difficult because infected fruit tend to drop from the tree soon after disease symptoms develop. Still, it can be conversely argued that the high incidence of $P$. syringae on orange fruit in the current study is due to infections originating from contact with contaminated leaf litter. The presence of $P$. syringae on citrus fruit could then be claimed to be due to baiting from litter, rendering it not a primary pathogen. This scenario, however, is unlikely because the majority of fruit were collected directly from the lower tree canopy, where most of the brown rot typically develops. Additionally, disease development after infection with $P$. syringae proceeds very slowly even at optimum environmental conditions, and symptoms are not evident until 2 to 3 weeks after inoculation (J. E. Adaskaveg, unpublished data), when fruit on the ground would likely have been partially decomposed by other organisms. Furthermore, $P$. syringae was detected in orange shipments to China, and commercially harvested fruit are never picked from the ground. Thus, fruit were most likely infected while on the tree. The finding that $P$. syringae inoculum is present in leaf litter does not affect our conclusions in this study on the current high incidence of $P$. syringae as a citrus brown rot pathogen in California.

The epidemiology of $P$. syringae is largely unknown, probably because this species previously was considered a minor problem in citrus. $P$. syringae was also shown to be present in leaf litter of almond, where this pathogen was causing pruning wound cankers (Doster and Bostock 1988). Leaf infection from inoculations has never been demonstrated. Additional studies are necessary to better understand the disease cycle and survival strategies of $P$. syringae. These epidemiological studies need to be continued because they may affect management strategies and assessment of disease risk.

Our study demonstrates that $P$. syringae is currently an important brown rot pathogen of citrus fruit in California during the cooler seasons of the year. The widespread distribution of the pathogen is of concern and warrants intensified management using cultural and chemical practices to ensure that disease levels are minimized, export of diseased fruit is prevented, and quarantine regulations are followed. The reason for the high increase of $P$. syringae and the apparent absence of $P$. nicotianae as a brown rot pathogen in California is not known. Our results also showed that multiplex TaqMan qPCR assays are an accurate and efficient tool to directly detect and identify Phytophthora spp. in citrus fruit.

\section{ACKNOWLEDGMENTS}

We thank D. A. Cary (University of California, Kearney Research and Extension Center) for collecting orange samples; L. Hou (University of California, Kearney Research and Extension Center) for assisting in DNA extractions; and M. D. Coffey (University of California, Riverside) for providing DNA of Phytophthora, Pythium, and Phytopythium spp. used for TaqMan $\mathrm{qPCR}$ probe validation.

\section{LITERATURE CITED}

Adaskaveg, J. E., and Förster, H. 2014. Integrated postharvest strategies for management of Phytophthora brown rot of citrus in the United States. Pages 123-131 in: Post-Harvest Pathology, Plant Pathology in the 21st Century. D. Prusky and M. L. Gullino, eds. Springer International Publishing, Cham, Switzerland. 
Bilodeau, G. J., Martin, F. N., Coffey, M. D., and Blomquist, C. L. 2014. Development of a multiplex assay for genus- and species-specific detection of Phytophthora based on differences in mitochondrial gene order. Phytopathology 104:733-748.

CDFA. 2015. California Agricultural Exports 2014-2015. Online publication. California Department of Food and Agriculture. https://www.cdfa.ca.gov/ Statistics/PDFs/AgExports2014-2015.pdf

Cooke, D. E., Drenth, A., Duncan, J. M., Wagels, G., and Brasier, C. M. 2000. A molecular phylogeny of Phytophthora and related oomycetes. Fungal Genet. Biol. 30:17-32.

Cooke, D. E., and Duncan, J. M. 1997. Phylogenetic analysis of Phytophthora species based on ITS1 and ITS2 sequences of the ribosomal RNA gene repeat. Mycol. Res. 101:667-677.

Dirac, M. F., Menge, J. A., and Madore, M. A. 2003. Comparison of seasonal infection of citrus roots by Phytophthora citrophthora and P. nicotianae var. parasitica. Plant Dis. 87:493-501.

Doster, M. A., and Bostock, R. M. 1988. Incidence, distribution, and development of pruning wound cankers caused by Phytophthora syringae in almond orchards in California. Phytopathology 78:468-472.

Eckert, J. W., and Brown, G. E. 1986. Postharvest citrus diseases and their control. Pages 315-360 in: Fresh Citrus Fruits. W. F. Wardowski, S. Nagy, and W. Grierson, eds. AVI, Westport, CT.

Eckert, J. W., and Eaks, I. L. 1989. Postharvest disorders and diseases of citrus fruits. Pages 179-260 in: The Citrus Industry. W. Reuther, ed. University of California Agriculture and Natural Resources, Oakland.

Erwin, D. C., and Ribeiro, O. K. 1996. Phytophthora Diseases Worldwide. The American Phytopathological Society Press, St. Paul, MN.

Feld, S. J., Menge, J. A., and Pehrson, J. E. 1979. Brown rot of citrus: A review of the disease. Citrograph 64:101-106.

Ferguson, A. J., and Jeffers, S. N. 1999. Detecting multiple species of Phytophthora in container mixes from ornamental crop nurseries. Plant Dis. 83:1129-1136.

Graham, J. H., and Menge, J. A. 2000. Phytophthora-induced diseases. Pages 12-15 in: Compendium of Citrus Diseases. L. W. Timmer, S. M. Garnsey, and J. H. Graham, eds. The American Phytopathological Society Press, St. Paul, MN.

Graham, J. H., and Timmer, L. W. 1995. Identification and control of Phytophthora species causing brown rot of citrus. Citrus Ind. 76:38-39.

Graham, J. H., Timmer, L. W., Drouillard, D. L., and Peever, T. L. 1998. Characterization of Phytophthora spp. causing outbreaks of citrus brown rot in Florida. Phytopathology 88:724-729.

Hao, W., Forster, H., Miles, T. D., Martin, F. N., Browne, G., and Adaskaveg, J. E. 2016. A leaf litter and fruit brown rot life style of Phytophthora syringae in California citrus. (Abstr.) Phytopathology 106:S4.132.
Judelson, H. S. 1996. Genetic and physical variability at the mating type locus of the oomycete, Phytophthora infestans. Genetics 144:1005-1013.

Jung, T., and Burgess, T. I. 2009. Re-evaluation of Phytophthora citricola isolates from multiple woody hosts in Europe and North America reveals a new species, Phytophthora plurivora sp. nov. Persoonia 22:95-110.

Klotz, L. J. 1978. Fungal, bacterial, and nonparasitic diseases and injuries originating in the seedbed, nursery, and orchard. Pages 1-66 in: The Citrus Industry, Vol. IV. Crop Protection. W. Reuther, E. C. Calavan, and G. E. Carman, eds. University of California, Division of Agricultural Sciences, Berkeley.

Martin, F. N. 2000. Phylogenetic relationships among some Pythium species inferred from sequence analysis of the mitochondrially encoded cytochrome oxidase II gene. Mycologia 92:711-727.

Martin, F. N., Blair, J. E., and Coffey, M. D. 2014. A combined mitochondrial and nuclear multilocus phylogeny of the genus Phytophthora. Fungal Genet. Biol. 66:19-32.

Martin, F. N., and Tooley, P. W. 2003. Phylogenetic relationships among Phytophthora species inferred from sequence analysis of mitochondrially encoded cytochrome oxidase I and II genes. Mycologia 95:269-284.

Martin, F. N., Tooley, P. W., and Blomquist, C. 2004. Molecular detection of Phytophthora ramorum, the causal agent of Sudden Oak Death in California, and two additional species commonly recovered from diseased plant material. Phytopathology 94:621-631.

Menge, J. A., Johnson, E. L. V., Pond, E., Ferrin, D., Liu, H., Lutz, A., Strother, M., Bartnicki, D., Afek, U., and Sjoerdsma, J. 1988. Distribution and frequency of Phytophthora parasitica and Phytophthora citrophthora associated with root rot of citrus in California. (Abstr.) Phytopathology 78:1576.

Miles, T. D., Martin, F. N., Robideau, G. P., Bilodeau, G. J., and Coffey, M. D. 2017. Systematic development of Phytophthora species-specific mitochondrial diagnostic markers for economically important members of the genus. Plant Dis. 101:1162-1170.

Ribeiro, O. K., Erwin, D. C., and Khan, R. A. 1978. New high-temperature Phytophthora pathogenic to roots of Alfalfa. Phytopathology 68:155-161.

Smith, R. E., and Ramsey, H. J. 1907. The Brown Rot of the Lemon. University of California, College of Agriculture, Agricultural Experiment Station, Berkeley.

White, T. J., Bruns, T., Lee, S., and Taylor, J. 1990. Amplification and direct sequencing of fungal ribosomal RNA genes for phylogenetics. Pages 315-322 in: PCR Protocols: A Guide to Methods and Applications. M. A. Innis, J. J. Gelfand, J. J. Sninsky, and T. J. White, eds. Academic Press, San Diego, CA. 